\title{
PENGARUH KUALITAS PELAYANAN DAN BAURAN PEMASARAN TERHADAP KEPUASAN PELANGGAN DAN IMPLIKASINYA PADA LOYALITAS PELANGGAN DI RUMAH MAKAN WAROENG DESA KARAWANG
}

\author{
Laras Ratu Khalida \\ larasratu407@gmail.com
}

\begin{abstract}
ABSTRAK
Rumah Makan Waroeng Desa merupakan rumah makan sederhana yang menyajikan masakan khas Sunda menggunakan konsep prasmanan (mengambil makanan sendiri) dan mempunyai menu makanan yang spesial dengan produk unggulannya dan citarasa yang khas. Didukung dengan bangunan yang unik dan tempat yang nyaman, menjadi minat tersendiri bagi konsumen yang datang. Secara umum penelitian ini bertujuan untuk mengetahui dan menjelaskan pengaruh kualitas pelayanan dan bauran pemasaran terhadap kepuasan pelanggan dan implikasinya pada loyalitas pelanggan di Rumah Makan Waroeng Desa Karawang. Metode penelitian ini dengan menggunakan metode deskriptif dan verifikatif. Variabel diukur menggunakan instrumen kuesioner dan skala pengukuran yang digunakan adalah skala Likert. Sampel dikumpulkan dengan menggunakan metode Sampling Incidental dengan jumlah sampel 160 responden dari populasi 2.051 orang. Teknik analisis data yang digunakan yaitu teknik Analisis Rentang Skala dan Analisis Jalur dengan bantuan Method of Successive Interval (MSI). Dari hasil analisis penelitian ini diperoleh beberapa kesimpulan yaitu :

1. Hubungan antara Kualitas Pelayanan dengan Bauran Pemasaran memiliki tingkat hubungan yang sangat rendah.

2. Terdapat pengaruh parsial kualitas pelayanan dan bauran pemasaran terhadap kepuasan pelanggan.

3. Terdapat pengaruh simultan antara Kualitas Pelayanan dan Bauran Pemasaran terhadap Kepuasan Pelanggan dan implikasinya pada Loyalitas Pelanggan

4. Total Pengaruh Kualitas Pelayanan dan Bauran Pemasaran memiliki kontribusi terhadap Kepuasan Pelanggan sebesar 46\% sedangkan sisanya 54\% merupakan kontribusi variabel lain $(\varepsilon)$ yang tidak diteliti.

5. Kepuasan Pelanggan berpengaruh terhadap Loyalitas Pelanggan Dengan demikian dapat disimpulkan bahwa kepuasan pelanggan (Y) berpengaruh secara positif dan signifikan terhadap loyalitas pelanggan $(\mathrm{Z})$.

Kata kunci : Kualitas Pelayanan, Bauran Pemasaran, Kepuasan Pelanggan, Loyalitas Pelanggan.
\end{abstract}




\title{
THE INFLUENCES OF QUALITY SERVICE AND MARKETING MIX TO CUSTOMER SATISFACTION AND THE IMPLICATIONS TO CUSTOMER LOYALTY IN RESTAURANT WAROENG DESA KARAWANG
}

\author{
Laras Ratu Khalida \\ larasratu407@gmail.com
}

\begin{abstract}
Restaurants Waroeng Desa is a simple restaurants presenting cookery in the buffet typical sundanesse (taking his own food) and has the special menu with top products and the good taste. Supported with buildings that unique and any convenient place, become the lack of interest in by himself and for consumers that make up the come. In general, this research aims to review and explain the influence of quality service and marketing mix to customer satisfaction and the implications to customer loyalty in restaurant waroeng desa karawang. The methodology using descriptive methods and verifikatif .Variable measured use instruments the questionnaire and scale of measurement used is likert scale. Sample collected by using the method of sampling incidental with the sample of the 160 respondents of the population 2.051 people. Technique analysis the data used the technique analysis range the scale and analysis path by assistance method of successive of the intervals ( MSI ). From the research analysis there are some conclusion that:

1. The relationship between the quality of services and marketing mix are very low

2. The partial influences the quality of service and marketing mix to customer satisfaction.

3. The simultaneous between quality of service and marketing mix to costumer satisfaction and the implications to costumer loyalty.

4. Total of quality of service and marketing mix have contributed to costumer satisfaction is $46 \%$ and the half is $54 \%$ was contributed by the other variables that doesn't be researched.

5. Had the influences between costumer satisfaction to costumer loyalty. This means that the costumer satisfaction (Y) influences positively and significantly to costumer loyalty $(\mathrm{Z})$.

Keyword : Quality of Service, Marketing Mix, Costumer Satisfaction, Costumer Loyalty
\end{abstract}




\section{PENDAHULUAN}

Kebutuhan manusia akan pangan selalu menjadi salah satu kebutuhan yang utama. Jumlah populasi manusia yang terus bertambah membuat kebutuhan akan pangan juga terus bertambah. Pengusaha dapat melihat hal ini sebagai prospek dalam berbisnis sesuai dengan adanya permintaan dan penawaran. Bisnis pangan khususnya di bidang rumah makan saat ini menunjukkan perkembangan yang baik dengan prospek usaha yang meningkat dan cukup pesat.

Rumah Makan termasuk dalam kategori jasa campuran atau Hybrid, yang terdiri dari barang dan jasa dengan proporsi yang sama seperti restoran yang harus didukung oleh makanan dan pelayanannya. Bisnis rumah makan merupakan usaha yang berhubungan langsung dengan pelanggan atau konsumen, sehingga segala yang dilakukan pengelola bisnis rumah makan disamping untuk memperoleh keuntungan juga bagaimana pengelola rumah makan dapat memuaskan konsumen. Karena dengan adanya kepuasan konsumen maka untuk selanjutnya konsumen akan memperlihatkan peluang membeli yang lebih tinggi dalam kesempatan berikutnya. Konsumen yang puas cenderung mengatakan sesuatu yang serba baik tentang rumah makan tersebut kepada orang lain. Sehingga orang lain akan berminat membeli pada rumah makan yang bersangkutan (Kotler, 2000;428).

Dalam membuka suatu usaha, pemerintah ikut berperan penting dalam pengelolaan usaha dengan mengeluarkan perlindungan hukum yang melindungi semua usaha, baik usaha mikro, kecil, dan menengah (UMKM) yang terletak pada Peraturan Pemerintah Republik Indonesia Nomor 17 Tahun 2013 Tentang Pelaksanaan Undang-Undang Nomor 20 Tahun 2008 Tentang Usaha Mikro, Kecil, Dan Menengah.

Perkembangan industri kecil seperti rumah makan di Karawang ini kian banyak seiring dengan bertambahnya kebutuhan pangan manusia. Terlebih lagi perkembangan dan peningkatan ekonomi di Indonesia menjadi salah satu faktor yang mempengaruhi tingginya perilaku konsumtif masyarakat. Tingkat persaingan antar rumah makan pun semakin tinggi. Oleh karena itu perusahaan harus dapat meningkatkan kualitasnya untuk menarik, mencari dan mempertahankan pelanggannya. Salah satunya dengan cara meningkatkan kualitas pelayanan dan bauran pemasaran agar konsumen melakukan pembelian pada rumah makan tersebut. Bauran pemasaran yang menarik serta pelayanan yang termanajamen dengan baik akan menjadikan nilai tersendiri bagi para konsumen.

Kepuasan konsumen terhadap perusahaan tidak terlepas dari jenis promosi yang digunakan dan kualitas pelayanan yang diberikan oleh perusahaan itu sendiri. Menurut Morissan (2007 : 18), promosi didefinisikan sebagai koordinasi dari seluruh upaya yang dimulai pihak penjual untuk membangun berbagai saluran informasi dan persuasi untuk menjual barang dan jasa atau memperkenalkan suatu gagasan.

Philip Kotler (2005) juga menjelaskan bahwa aktivitas promosi merupakan usaha pemasaran yang memberikan berbagai upaya intensif jangka pendek untuk mendorong keinginan mencoba atau membeli suatu produk atau jasa. Seluruh kegiatan promosi bertujuan untuk mempengaruhi perilaku pembelian, tetapi tujuan promosi yang utama adalah memberitahukan, membujuk dan mengingatkan kembali konsumen terhadap sebuah produk atau jasa. 
Kualitas pelayanan merupakan faktor yang mempengaruhi tingkat kepuasan konsumen. Perusahaan yang mengutamakan kualitas pelayanan yang baik akan berdampak pada kepuasan pelanggan (Walker, 2001 : 35). Dengan adanya kualitas pelayanan yang telah diberikan, maka secara tidak langsung kepuasan konsumen akan terwujud. Bagi perusahaan yang bergerak dibidang kuliner, kualitas pelayanan menjadi suatu hal yang penting. Kualitas pelayanan merupakan sebuah tingkatan kemampuan (ability) dari perusahaan dalam memberikan segala yang menjadi harapan pelanggan dalam memenuhi kebutuhannya.

Rumah Makan Waroeng Desa merupakan rumah makan sederhana yang menyajikan masakan khas Sunda menggunakan konsep prasmanan (mengambil makanan sendiri) dan mempunyai menu makanan yang spesial dengan produk unggulannya dan citarasa yang khas. Didukung dengan bangunan yang unik dan tempat yang nyaman, menjadi minat tersendiri bagi konsumen yang datang.

Sebelumnya peneliti melakukan penelitian terlebih dahulu dengan mewawancarai terhadap beberapa pengunjung yang datang ke rumah makan Waroeng Desa. Beberapa pengunjung tersebut menyatakan bahwa mereka sangat menikmati masakan yang disajikan, dan menurut mereka masakan yang disajikan seperti masakan di rumah. Terlebih juga dengan harga yang ditawarkan oleh rumah makan terjangkau oleh semua kalangan, termasuk mahasiswa.

Namun beberapa bulan terakhir, rumah makan mengalami sedikit masalah tentang jumlah pengunjung yang mengalami penurunan yang cukup signifikan, kurangnya promosi dan karyawan kurang cepat dalam menyajikan minuman dan makanan yang dipesan oleh konsumen.

Perusahaan harus memperhatikan kekurangannya tersebut diatas karena akan mempengaruhi kepuasan pelanggan yang menyebabkan loyalitas pelanggan semakin menurun. Oleh karena itu, Rumah Makan Waroeng Desa harus mampu melakukan perubahan strategi dan mampu mengimbangi produk-produk para kompetitor, yang tidak menutup kemungkinan melebihi produk yang ada pada Rumah Makan Waroeng Desa baik dari segi kualitas produk, promosi, fasilitas, harga dan pelayanan.

Berdasarkan uraian di atas, maka penulis merasa tertarik untuk melakukan penelitian tentang kualitas pelayanan, bauran pemasaran, kepuasan pelanggan dan loyalitas pelanggan yang dilakukan di Rumah Makan Waroeng Desa. Maka didalam penyusunan penelitian ini, penulis mengambil judul : PENGARUH KUALITAS PELAYANAN DAN BAURAN PEMASARAN TERHADAP KEPUASAN PELANGGAN DAN IMPLIKASINYA PADA LOYALITAS PELANGGAN DI RUMAH MAKAN WAROENG DESA KARAWANG.

\section{IDENTIFIKASI MASALAH}

Berdasarkan latar belakang penelitian, maka masalah tersebut dapat diidentifikasi sebagai berikut :

1. Semakin banyaknya bisnis rumah makan, semakin banyak competitor nya.

2. Bauran pemasaran yang kurang efektif

3. Adanya keluhan mengenai kurang cepatnya karyawan dalam menyajikan minuman dan makanan yang dipesan konsumen.

4. Citra perusahaan dimata pelanggan kurang terkenal. 


\section{RUMUSAN MASALAH}

Berdasarkan dari uraian di atas, maka penulis merumuskan masalah yaitu sebagai berikut :

1. Bagaimana kualitas pelayanan di Rumah Makan Waroeng Desa?

2. Bagaimana bauran pemasaran di Rumah Makan Waroeng Desa?

3. Bagaimana kepuasan pelanggan di Rumah Makan Waroeng Desa?

4. Bagaimana loyalitas pelanggan di Rumah Makan Waroeng Desa?

5. Seberapa besar korelasi antara kualitas pelayanan dan bauran pemasaran di Rumah Makan Waroeng Desa?

6. Seberapa besar pengaruh parsial kualitas pelayanan dan bauran pemasaran terhadap kepuasan pelanggan di Rumah Makan Waroeng Desa?

7. Seberapa besar pengaruh simultan kualitas pelayanan dan bauran pemasaran terhadap kepuasan pelanggan di Rumah Makan Waroeng Desa?

8. Seberapa besar pengaruh kepuasan pelanggan terhadap loyalitas pelanggan?

\section{TUJUAN PENELITIAN}

Sesuai dengan identifikasi masalah, maka yang menjadi tujuan penelitian ini adalah untuk menyelesaikan masalah serta mengetahui dan menganalisis :

1. Untuk mengetahui, menganalisis dan menjelaskan kualitas pelayanan di Rumah Makan Waroeng Desa.

2. Untuk mengetahui, menganalisis dan menjelaskan bauran pemasaran di Rumah Makan Waroeng Desa.

3. Untuk mengetahui, menganalisis dan menjelaskan kepuasan pelanggan di Rumah Makan Waroeng Desa

4. Untuk mengetahui, menganalisis dan menjelaskan loyalitas pelanggan di Rumah Makan Waroeng Desa

5. Untuk mengetahui, menganalisis dan menjelaskan seberapa besar korelasi antara kualitas pelayanan dengan bauran promosi di Rumah Makan Waroeng Desa

6. Untuk mengetahui, menganalisis dan menjelaskan seberapa besar pengaruh parsial kualitas pelayanan dan bauran promosi terhadap kepuasan pelanggan di Rumah Makan Waroeng Desa.

7. Untuk mengetahui, menganalisis dan menjelaskan seberapa besar pengaruh simultan kualitas pelayanan dan bauran promosi terhadap kepuasan pelanggan di Rumah Makan Waroeng Desa.

8. Untuk mengetahui, menganalisis dan menjelaskan seberapa besar pengaruh kepuasan pelanggan terhadap loyalitas pelanggan.

\section{TINJAUAN PUSTAKA}

\section{KUALITAS PELAYANAN}

Menurut Kotler dan Keller (2012: 131), mendefinisikan kualitas pelayanan adalah kemampuan perusahaan untuk memuaskan kebutuhan dan keinginan konsumen. Berdasarkan definisi ini, kualitas pelayanan ditentukan oleh kemampuan perusahaan memenuhi kebutuhan dan keinginan konsumen sesuai dengan ekspektasi konsumen.

18. 
Menurut Lovelock (2002 : 87) yang dikutip oleh Whidya Utami (2010 : 291) bahwa kualitas layanan adalah perspektif pelanggan dalam jangka panjang dan merupakan evaluasi kognitif dari transfer jasa.

Pengukuran terhadap kualitas pelayanan dinyatakan dalam lima dimensi kualitas pelayanan jasa. Lima dimensi kualitas pelayanan tersebut menurut Kotler dan Keller (2012:374), adalah :

1. Bukti Fisik (Tangible)

2. Empati (Empathy)

3. Kehandalan (Reliability)

4. Daya Tanggap (Responsiveness)

5. Jaminan (Assurance)

\section{BAURAN PEMASARAN}

Bauran pemasaran (4P) terdiri atas produk, harga, distribusi dan promosi. Pengertian bauran pemasaran (Marketing Mix) menurut Kotler \& Armstrong (2012 : 51) adalah sebagai berikut: The set of tactical marketing tools product, price, place and promotion that the firm blends to produce the response it wants in the target market. Artinya seperangkat alat pemasaran taktis terdiri atas produk, harga, tempat dan promosi bahwa perusahaan memadukan untuk menghasilkan respon yang diinginkan dalam pasar sasaran.

Pengertian unsur-unsur tersebut adalah sebagai berikut :

1. Produk (Product)

Kombinasi antara barang dan jasa dari perusahaan yang dapat ditawarkan kepada pasar sasaran untuk memenuhi kebutuhan dan keinginan tertentu.

2. Harga (Price)

Sejumlah uang yang harus dibayar untuk mendapatkan suatu produk. Strategi dalam harga juga dapat meliputi diskon, syarat pembayaran, dll.

3. Tempat (Place)

Meliputi kegiatan perusahaan yang membuat produk yang tersedia untuk dapat dijangkau oleh konsumen.

4. Promosi (Promotion)

Berarti kegiatan yang dilakukan oleh perusahaan untuk mengkonsumsikan manfaat produk dan membujuk konsumen untuk membelinya.

\section{KEPUASAN PELANGGAN}

Menurut Phillip Kotler dan Kevin Lane Keller (2007:177), kepuasan konsumen adalah perasaan senang atau kecewa seseorang yang muncul setelah membandingkan kinerja (hasil) produk yang dipikirkan terhadap kinerja yang diharapkan.

Menurut Tjiptono (2012:301), kepuasan konsumen merupakan situasi yang ditunjukkan oleh konsumen ketika mereka menyadari bahwa kebutuhan dan keinginannya sesuai dengan yang diharapkan serta terpenuhi secara baik.

Pengukuran kepuasan pelanggan memiliki tiga aspek yang saling berkaitan, yaitu:

1. Apa yang diukur

19. 
Menentukan aspek-aspek apa yang diukur tidak satu pun ukuran tunggal terbaik mengenai kepuasan pelanggan yang disepakati secara universal. Meskipun demikian, ditengah beragamnya cara mengukur kepuasan pelanggan, terdapat kesamaan paling tidak dalam enam konsep inti (Tjiptono, 2000:101):

a. Kepuasan pelanggan keseluruhan (Overall Customer Satisfaction).

Cara yang paling sederhana untuk mengukur kepuasan pelanggan adalah langsung menanyakan kepada pelanggan seberapa puas mereka dengan produk atau jasa spesifik tertentu.

Ada 2 bagian dalam proses pengukurannya, yaitu:

1) Mengukur tingkat kepuasan pelanggan terhadap produk atau jasa perusahaan bersangkutan.

2) Menilai dan membandingkan dengan tingkat kepuasan pelanggan keseluruhan terhadap produk atau jasa para pesaing.

b. Dimensi kepuasan pelanggan

Berbagai penelitian memilah kepuasan pelanggan ke dalam komponenkomponennya.

c. Konfirmasi Harapan (Confirmation of Expectation)

Dalam konsep ini kepuasan tidak diukur langsung, tetapi disimpulkan berdasar kesesuaian atau ketidaksesuaian antara harapan pelanggan dengan kinerja aktual perusahaan.

d. Minat pembelian ulang (Repurchase Intent)

Kepuasan pelanggan diukur dengan menanyakan apakah pelanggan akan berbelanja atau mau menggunakan jasa perusahaan tersebut lagi.

e. Kesediaan untuk merekomendasi (Willingness to Recommend)

Kepuasan pelanggan dapat diukur dengan menanyakan apakah pelanggan merekomendasikan produk tersebut kepada keluarga atau teman.

\section{LOYALITAS PELANGGAN}

Menurut Oliver yang dikutip Hurriyati (2010 : 129), "Customer loyalty is deeply held commitment to rebuy or repatnorize a preffered product or service consistently in future, despite situational influences and marketing effort having the potential to cause switching behavior". Dari definisi tersebut dapat didefinisikan bahwa loyalitas adalah komitmen pelanggan bertahan secara mendalam untuk berlangganan kembali atau melakukan pembelian ulang produk atau jasa terpilih sebagai sikap konsisten dimasa yang akan datang, meskipun pengaruh situasi dan usaha-usaha pemasaran mempunyai potensi untuk menyebabkan perubahan perilaku.

Pelanggan yang loyal merupakan asset penting bagi perusahaan, hal ini dapat dilihat dari karakteristik yang dimilikinya, sebagaimana yang diungkapkan Griffin (2002 : 31) dalam Ratih Hurriyati (2010 : 130), dimana pelanggan yang loyal memiliki karakteristik sebagai berikut :

a) Melakukan pembelian secara teratur (Makes regular repeat purchases).

b) Membeli diluar lini produk/jasa (Purchases across product and services lines).

c) Merekomedasikan produk kepada orang lain (Refers others).

d) Menunjukkan kekebalan dari daya Tarik produk sejenis dari pesaing (Demonstrates an immunity to the full of competition). 
Menurut Zeithmal (dalam Fajar Laksana 2008:185) terdapat empat dimensi dari loyalitas pelanggan, yaitu:

1. Word of Mouth Communications

2. Purchase Intentions

3. Price Sensivity

4. Complaining Behavior

\section{Paradigma Penelitian}

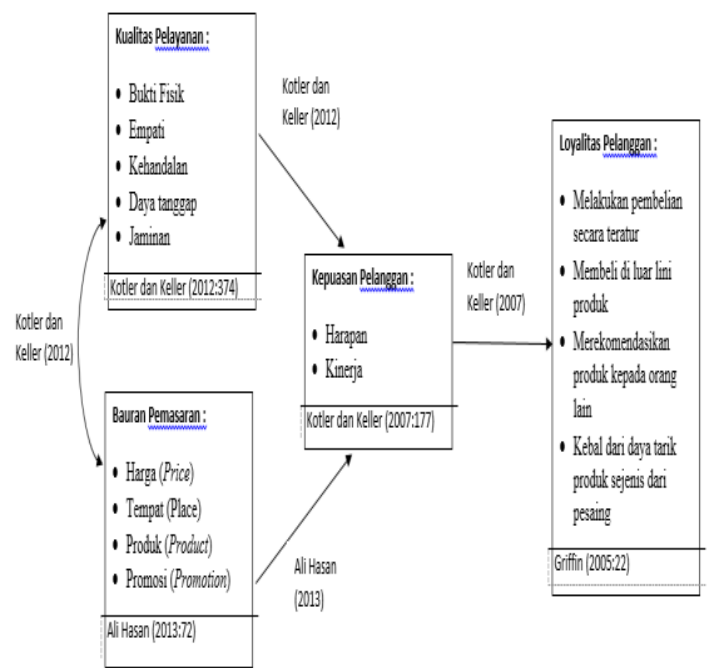

Gambar 1. Paradigma Penelitian

\section{Hipotesa Penelitian}

Dalam penelitian ini hipotesis yang diajukan adalah :

1. Terdapat korelasi antara kualitas pelayanan, bauran pemasaran, kepuasan pelanggan dan loyalitas pelanggan di Rumah Makan Waroeng Desa Karawang

2. Terdapat pengaruh parsial kualitas pelayanan, bauran pemasaran dan kepuasan pelanggan terhadap loyalitas pelanggan di Rumah Makan Waroeng Desa Karawang

3. Terdapat pengaruh simultan kualitas pelayanan, bauran pemasaran dan kepuasan pelanggan terhadap loyalitas pelanggan di Rumah Makan Waroeng Desa Karawang

4. Terdapat pengaruh kepuasan pelanggan terhadap loyalitas.

\section{METODE PENELITIAN}

\section{JENIS PENELITIAN}

Pada penelitian ini menggunakan metode kuantitatif dengan tujuan penelitian yang berupaya untuk memberikan generalisasi mengenai pengaruh kualitas pelayanan dan bauran pemasaran terhadap kepuasan pelanggan dan implikasinya pada loyalitas pelanggan.

Secara deskriptif penelitian ini bertujuan untuk memperoleh gambaran mengenai variabel Kualitas Pelayanan, Bauran Pemasaran dan variabel Kepuasan Pelanggan sebagai variabel bebasnya dan Loyalitas Pelanggan sebagai variabel 
terikat. Sedangkan secara verifikatif bertujuan untuk menguji hipotesis dengan perhitungan statistik.

\section{Operasionalisasi Variabel}

Dalam penelitian ini peneliti menggunakan tiga variabel yaitu dua variabel bebas $\left(\mathrm{X}_{1}\right.$ dan $\left.\mathrm{X}_{2}\right)$ dan dua variabel terikat ( $\mathrm{Y}$ dan $\mathrm{Z}$ ). Dalam hal ini variabel $\mathrm{X}_{1}$ adalah kualitas pelayanan dan variabel $\mathrm{X}_{2}$ adalah bauran pemasaran merupakan variabel yang mempengaruhi variabel $\mathrm{Y}$ yaitu kepuasan pelanggan dan variabel $\mathrm{Z}$ yaitu loyalitas pelanggan di Rumah Makan Waroeng Desa Karawang.

\section{Sumber Dan Cara Penentuan Data/Informasi}

Jenis data yang digunakan dalam penelitian ini adalah data primer dan data sekunder.

1. Data Primer

Pengumpulan data primer dalam penelitian ini melalui cara menyebarkan kuesioner kepada pengunjung yang datang ke Rumah Makan Waroeng Desa.

2. Data Sekunder

Dalam hal ini penulis mengumpulkan data secara library research, yaitu dengan melihat buku-buku (literature) yang berhubungan dengan masalah penelitian dan dapat melengkapi/mendukung data primer.

\section{Populasi Dan Sampel}

Dalam penelitian ini populasinya adalah pengunjung di Rumah Makan Waroeng Desa Karawang. Populasi yang diambil dari jumlah data pengunjung 6 bulan yang lalu, yaitu sekitar 2.051 orang.

Adapun peneliti menggunakan rumus Slovin. Rumus Slovin untuk menentukan sampel adalah :

Keterangan :

$$
\mathrm{n}=\frac{N}{1+\mathrm{N}(e)^{2}}
$$

$\mathrm{n}=$ Ukuran sampel/jumlah responden

$\mathrm{N}=$ Ukuran populasi

$\mathrm{e}=$ Persentase kelonggaran ketelitian kesalahan pengambilan sampel yang masih bisa ditolerir; $\mathrm{e}=0,05$

Jumlah populasi dalam penelitian ini adalah 2.051 orang, sehingga persentase kelonggaran yang digunakan adalah 5\%. Maka untuk mengetahui sampel penelitian, berikut perhitungannya :

$$
\mathrm{n}=\frac{2.051}{1+2.051(0,05)^{2}}=159,92 \text { dibulatkan } 160
$$

Jumlah sampel dibulatkan menjadi 160 orang

Berdasarkan perhitungan di atas, sampel yang menjadi responden dalam penelitian ini sebanyak 160 orang, sampel diambil berdasarkan teknik probability sampling, simple random sampling, dimana peneliti memberikan peluang yang sama bagi setiap unsur (anggota) populasi untuk dipilih menjadi anggota sampel yang dilakukan secara acak tanpa memperhatikan strata yang ada dalam populasi itu sendiri. 


\section{Teknik Pengumpulan Data}

Pada penelitian ini menggunakan metode pengumpulan data sebagai berikut:

1. Penelitian Lapangan (Field Research)

Dalam penelitian lapangan tersebut penulis menggunakan beberapa prosedur yaitu :

a. Angket

b. Observasi

c. Wawancara

Pada penelitian ini, penulis melakukan wawancara terhadap konsumen Rumah Makan Waroeng Desa Karawang.

2. Penelitian Kepustakaan (Library Research)

Yaitu mencari, mempelajari dan mengumpulkan teori serta bahan-bahan yang mendukung bagi penulis dengan mempelajari informasi dari beberapa literature yang berkaitan dengan masalah yang sedang diteliti penulis

\section{Rancangan Analisis dan Uji Hipotesis \\ Rancangan Analisis Deskriptif}

Analisis deskriptif menggunakan skala ordinal dan rentang skala untuk menganalisis data dengan cara menggambarkan Kualitas Pelayanan dan Bauran Pemasaran terhadap Kepuasan Pelanggan dan implikasinya pada Loyalitas Pelanggan di Rumah Makan Waroeng Desa Karawang

Untuk menentukan skala prioritas dari setiap variabel yang diukur selanjutnya dihitung skala dari skor yang diukur dengan menggunakan analisis rentang skala.

\section{Uji Hipotesis}

\section{Uji Hipotesis (Uji t)}

Untuk mengetahui besarnya pengaruh masing-masing variabel independen secara individual (parsial) terhadap variabel dependen. Hasil uji thitung ini ada pada output perangkat lunak, dapat dilihat pada tabel coefficient level of significance yang digunakan sebesar 5\% atau (a) =0,05. Apabila $t_{\text {hitung }}>t_{\text {tabel }}$ maka $\mathrm{H}_{0}$ ditolak dan $\mathrm{H}_{\mathrm{a}}$ diterima, artinya variabel independen secara parsial tidak mempunyai pengaruh yang signifikan terhadap variabel dependen.

\section{HASIL DAN PEMBAHASAN}

\section{A. Analisis Deskriptif}

\section{1) Analisis Validitas Data}

Berdasarkan hasil uji validitas pada semua variabel dengan menggunakan SPSS terlihat pada kolom corrected item-total correlation dan hasilnya tidak ada yang negatif dan lebih dari 0,3 untuk semua pernyataan.

\section{2) Analisis Reliabilitas Data}

Dengan menggunakan SPSS 19, hasil uji reliabilitas dari semua variabel menunjukkan sudah reliable karena nilai variabel tersebut sudah diatas 0,60.

\section{3) Uji Normalitas}

Uji normalitas bertujuan untuk menguji apakah dalam sebuah model regresi, variabel dependen memiliki distribusi normal atau tidak. Dari hasil uji normalitas, telah didapat hasilnya untuk variabel Kualitas Pelayanan $\left(X_{1}\right)=2,027$, variabel 
Bauran Pemasaran $\left(\mathrm{X}_{2}\right)=0,776$, variabel Kepuasan Pelanggan $(\mathrm{Y})=1,283$, dan variabel Loyalitas Pelanggan $(Z)=1,128$. Nilai signifikan $>0,05$, sehingga hasilnya menunjukkan semua variabel berdistribusi normal.

\section{B. Pengujian Hipotesis}

\section{a. Korelasi antara Kualitas Pelayanan $\left(\mathbf{X}_{1}\right)$ dan Bauran Pemasaran $\left(\mathbf{X}_{2}\right)$}

Pengujian hipotesis korelasi antara kualitas pelayanan $\left(\mathrm{X}_{1}\right)$ dan bauran pemasaran $\left(\mathrm{X}_{2}\right)$ dilakukan dengan menggunakan uji statistic t yaitu dengan rumus sebagai berikut (Riduwan, 2010:137) :

$$
\mathrm{t}=\frac{r \sqrt{n-2}}{\sqrt{1-r^{2}}}
$$

Diketahui :

$$
\begin{aligned}
& r=0,113 \\
& n=160
\end{aligned}
$$

Maka :

$$
\begin{aligned}
& t=\frac{0,113 \sqrt{160-2}}{\sqrt{1-0,113^{2}}} \\
& t=\frac{0,113(12,569)}{\sqrt{1-0,012}} \\
& t=\frac{1,420}{0,993} \\
& t=1,430
\end{aligned}
$$

Harga $t_{\text {hitung }}$ di atas selanjutnya dibandingkan dengan $t_{\text {tabel }}$ pada tingkat kesalahan $5 \%, \mathrm{db}=\mathrm{n}-2=160-2=158$, maka diperoleh $\mathrm{t}$ tabel $=1,960$. Dengan demikian diketahui $t_{\text {hitung }}(1,430)<t_{\text {tabel }}(1,960)$, maka dapat dinyatakan bahwa $\mathrm{H}_{0}$ diterima, artinya hubungan tidak signifikan antara kualitas pelayanan $\left(\mathrm{X}_{1}\right)$ dan bauran pemasaran $\left(\mathrm{X}_{2}\right)$.

\section{b. Hipotesis Pengaruh Variabel Secara Parsial}

1) Hipotesis pengaruh kualitas pelayanan $\left(\mathrm{X}_{1}\right)$ terhadap kepuasan pelanggan $(\mathrm{Y})$

Untuk Kualitas Pelayanan $\left(\mathrm{X}_{1}\right)$ terhadap kepuasan pelanggan $(\mathrm{Y})$ dengan tingkat signifikan $(\alpha)=5 \%$, degree of freedom $(\mathrm{df})=\mathrm{n}-2=160-2=158$ diperoleh $\mathrm{t}_{\text {tabel }}=1,960$ dengan hasil $\mathrm{t}_{\text {hitung }} 4,075$. Hal ini menunjukkan bahwa nilai sig. $(0,000)<\alpha(0,05)$ dan $t_{\text {hitung }}(4,075)>t_{\text {tabel }}(1,960)$, maka $\mathrm{H}_{0}$ ditolak. Dengan demikian dapat disimpulkan bahwa kualitas pelayanan berpengaruh terhadap kepuasan pelanggan.

2) Hipotesis pengaruh bauran pemasaran $\left(\mathrm{X}_{2}\right)$ terhadap kepuasan pelanggan $(\mathrm{Y})$

Untuk Bauran Pemasaran $\left(\mathrm{X}_{2}\right)$ terhadap kepuasan pelanggan $(\mathrm{Y})$ dengan tingkat signifikan $(\alpha)=5 \%$, degree of freedom $(\mathrm{df})=\mathrm{n}-2=160-2=158$ diperoleh $\mathrm{t}_{\text {tabel }}=1,960$ dengan hasil thitung 9,639. Hal ini menunjukkan bahwa nilai sig. $(0,000)<\alpha(0,05)$ dan $t_{\text {hitung }}(9,639)>t_{\text {tabel }}(1,960)$, maka $\mathrm{H}_{0}$ ditolak. Dengan demikian dapat disimpulkan bahwa bauran pemasaran berpengaruh terhadap kepuasan pelanggan.

3) Hipotesis Pengaruh Variabel Secara Simultan

Untuk kualitas pelayanan $\left(\mathrm{X}_{1}\right)$ dan bauran pemasaran $\left(\mathrm{X}_{2}\right)$ secara simultan (keseluruhan) terhadap kepuasan pelanggan (Y) dan implikasinya pada loyalitas pelanggan $(Z)$ dengan tingkat signifikan $(\alpha)=5 \%$, degree of freedom $(\mathrm{df})=\mathrm{n}-$ 
$2=160-2=158$ diperoleh $\mathrm{f}_{\text {tabel }}=3,91$ dengan $\mathrm{f}_{\text {hitung }}=59.958$ dan sig. 0,000 . Hal ini menunjukkan bahwa nilai sig. $(0,000)<\alpha(0,05)$ dan $f_{\text {hitung }}(59.958)>$ $t_{\text {tabel }}(3,91)$, maka $\mathrm{H}_{0}$ ditolak. Dengan demikian dapat disimpulkan bahwa kualitas pelayanan dan bauran pemasaran berpengaruh simultan terhadap kepuasan pelanggan dan implikasinya pada loyalitas pelanggan.

4) Hipotesis pengaruh kepuasan pelanggan $(Y)$ terhadap loyalitas pelanggan $(Z)$

Untuk Kepuasan Pelanggan (Y) terhadap loyalitas pelanggan $(\mathrm{Z})$ dengan tingkat signifikan $(\alpha)=5 \%$, degree of freedom $(\mathrm{df})=\mathrm{n}-2=160-2=158$ diperoleh $\mathrm{t}_{\text {tabel }}=1,960$ dengan nilai $\mathrm{t}_{\text {hitung }} 2,965$. Hal ini menunjukkan bahwa nilai sig. $(0,000)<\alpha(0,05)$ dan thitung $(2,965)>t_{\text {tabel }}(1,960)$, maka $\mathrm{H}_{0}$ ditolak. Dengan demikian dapat disimpulkan bahwa kepuasan pelanggan berpengaruh terhadap loyalitas pelanggan.

\section{Pembahasan Deskriptif}

Adapun pembahasan dari metode deskriptif mengenai masing-masing variabel dalam penelitian ini dapat diuraikan sebagai berikut.

1. Kualitas pelayanan pada Rumah Makan Waroeng Desa Karawang memiliki skor 628 terletak pada rentang skala 160 - 800 dengan kriteria setuju, artinya pelanggan memberikan respon yang baik terhadap kualitas pelayanan yang diterapkan selama ini di Rumah Makan Waroeng Desa Karawang.

2. Bauran pemasaran pada Rumah Makan Waroeng Desa Karawang memiliki skor 604 terletak pada rentang skala 160 - 800 dengan kriteria setuju, artinya pelanggan memberikan respon yang baik terhadap bauran pemasaran yang sudah dilakukan selama ini oleh Rumah Makan Waroeng Desa Karawang.

3. Kepuasan pelanggan pada Rumah Makan Waroeng Desa Karawang memiliki skor 601 terletak pada rentang skala 160 - 800 dengan kriteria setuju, artinya pelanggan memberikan merasa puas atas pelayanan yang diterapkan selama ini di Rumah Makan Waroeng Desa Karawang.

4. Loyalitas pelanggan pada Rumah Makan Waroeng Desa Karawang memiliki skor 601,8 terletak pada rentang skala 160 - 800 dengan kriteria setuju, artinya pelanggan cukup loyal terhadap Rumah Makan Waroeng Desa Karawang.

\section{Pembahasan Verifikatif}

1. Korelasi antara Kualitas Pelayanan $\left(X_{1}\right)$ dengan Bauran Pemasaran $\left(X_{2}\right)$ memiliki nilai koefisien korelasi sebesar 0,113 dan memiliki tingkat hubungan yang sangat rendah.

2. Pengaruh parsial kualitas pelayanan $\left(X_{1}\right)$ dan bauran pemasaran $\left(X_{2}\right)$ terhadap kepuasan pelanggan (Y).

a. Pengaruh Parsial Kualitas Pelayanan $\left(\mathrm{X}_{1}\right)$ terhadap Kepuasan Pelanggan (Y) adalah sebesar 0,060 . Hal ini menunjukkan pengaruh positif antara kualitas pelayanan $\left(\mathrm{X}_{1}\right)$ terhadap kepuasan pelanggan $(\mathrm{Y})$.

b. Pengaruh Parsial Bauran Pemasaran $\left(\mathrm{X}_{2}\right)$ terhadap Kepuasan Pelanggan ( $\mathrm{Y}$ ) adalah sebesar 0,339 . Hal ini menunjukkan pengaruh positif antara bauran pemasaran $\left(\mathrm{X}_{2}\right)$ terhadap kepuasan pelanggan (Y). Karena 0,339 lebih besar dari 0,060, maka dapat dinyatakan bahwa variabel bauran pemasaran lebih 
banyak memberikan pengaruh terhadap bauran pemasaran dibandingkan variable kualitas pelayanan.

3. Kualitas Pelayanan (X1) dan Bauran Pemasaran (X2) berpengaruh terhadap Kepuasan Pelanggan (Y) dan implikasinya pada Loyalitas Pelanggan dengan kriteria nilai uji nilai sig. $(0,000)<\alpha(0,05)$ dan $\mathrm{f}_{\text {hitung }}(59.958)>\mathrm{t}_{\text {tabel }}(3,91)$, maka $\mathrm{H}_{0}$ ditolak. Total Pengaruh Kualitas Pelayanan (X1) dan Bauran Pemasaran (X2) memiliki kontribusi terhadap Kepuasan Pelanggan (Y) sebesar $46 \%$ sedangkan sisanya 54\% merupakan kontribusi variabel lain ( $(\varepsilon)$ yang tidak diteliti.

4. Kepuasan Pelanggan ( $\mathrm{Y}$ ) berpengaruh terhadap Loyalitas Pelanggan ( $\mathrm{Z}$ ) dengan kriteria nilai uji nil sig. $(0,000)<\alpha(0,05)$ dan $t_{\text {hitung }}(2,965)>t_{\text {tabel }}$ (1,960), maka $\mathrm{H}_{0}$ ditolak. Dengan demikian dapat disimpulkan bahwa kepuasan pelanggan $(\mathrm{Y})$ berpengaruh secara positif dan signifikan terhadap loyalitas pelanggan $(Z)$.

\section{SIMPULAN DAN SARAN}

\section{a. Simpulan}

Berdasarkan tujuan penelitian yang dikemukakan dan selanjutnya dibandingkan dengan hasil penelitian dan pembahasan maka dapat dibuat kesimpulan sebagai berikut:

1. Kualitas Pelayanan di Rumah Makan Waroeng Desa Karawang memiliki skor 628 terletak pada rentang skala 160 - 800 dengan kriteria setuju, artinya pelanggan memberikan respon yang baik terhadap kualitas pelayanan yang diterapkan selama ini di Rumah Makan Waroeng Desa Karawang. Namun masih ada beberapa indikator yang memiliki nilai terendah yaitu kebersihan dan kelengkapan fasilitas.

2. Bauran pemasaran pada Rumah Makan Waroeng Desa Karawang memiliki skor 604 terletak pada rentang skala 160 - 800 dengan kriteria setuju, artinya pelanggan memberikan respon yang baik terhadap bauran pemasaran yang sudah dilakukan selama ini oleh Rumah Makan Waroeng Desa Karawang. Namun masih ada beberapa indikator yang memiliki nilai terendah yaitu tidak ada pemberian diskon, promosi melalui media cetak serta toilet dan mushola yang kurang bersih.

3. Kepuasan pelanggan pada Rumah Makan Waroeng Desa Karawang memiliki skor 601 terletak pada rentang skala 160 - 800 dengan kriteria setuju, artinya pelanggan memberikan merasa puas atas pelayanan yang diterapkan selama ini di Rumah Makan Waroeng Desa Karawang. Namun ada indikator yang memiliki nilai terendah yaitu kenyamanan.

4. Loyalitas pelanggan pada Rumah Makan Waroeng Desa Karawang memiliki skor 601,8 terletak pada rentang skala 160 - 800 dengan kriteria setuju, artinya pelanggan cukup loyal terhadap Rumah Makan Waroeng Desa Karawang.

5. Hubungan antara Kualitas Pelayanan $\left(\mathrm{X}_{1}\right)$ dengan Bauran Pemasaran $\left(\mathrm{X}_{2}\right)$ memiliki nilai koefisien korelasi sebesar 0,113 dan memiliki tingkat hubungan yang sangat rendah. 
6. Pengaruh parsial kualitas pelayanan $\left(\mathrm{X}_{1}\right)$ dan bauran pemasaran $\left(\mathrm{X}_{2}\right)$ terhadap kepuasan pelanggan $(\mathrm{Y})$.

a) Pengaruh Parsial Kualitas Pelayanan $\left(\mathrm{X}_{1}\right)$ terhadap Kepuasan Pelanggan (Y) adalah sebesar 0,246. Hal ini menunjukkan pengaruh positif antara kualitas pelayanan $\left(\mathrm{X}_{1}\right)$ terhadap kepuasan pelanggan $(\mathrm{Y})$

b) Pengaruh Parsial Bauran Pemasaran $\left(\mathrm{X}_{2}\right)$ terhadap Kepuasan Pelanggan (Y) adalah sebesar 0,583. Hal ini menunjukkan pengaruh positif antara bauran pemasaran $\left(\mathrm{X}_{2}\right)$ terhadap kepuasan pelanggan (Y). Karena 0,583 lebih besar dari 0,246, maka dapat dinyatakan bahwa variabel bauran pemasaran lebih banyak memberikan pengaruh terhadap bauran pemasaran dibandingkan variable kualitas pelayanan.

7. Kualitas Pelayanan (X1) dan Bauran Pemasaran (X2) berpengaruh terhadap Kepuasan Pelanggan (Y) dan implikasinya pada Loyalitas Pelanggan dengan kriteria nilai uji nilai sig. $(0,000)<\alpha(0,05)$ dan $f_{\text {hitung }}(59.958)>t_{\text {tabel }}(3,91)$, maka $\mathrm{H}_{0}$ ditolak. Total Pengaruh Kualitas Pelayanan (X1) dan Bauran Pemasaran (X2) memiliki kontribusi terhadap Kepuasan Pelanggan (Y) sebesar $46 \%$ sedangkan sisanya 54\% merupakan kontribusi variabel lain $(\varepsilon)$ yang tidak diteliti.

8. Kepuasan Pelanggan (Y) berpengaruh terhadap Loyalitas Pelanggan (Z) dengan kriteria nilai uji nil sig. $(0,000)<\alpha(0,05)$ dan $t_{\text {hitung }}(2,965)>t_{\text {tabel }}(1,960)$, maka $\mathrm{H}_{0}$ ditolak. Dengan demikian dapat disimpulkan bahwa kepuasan pelanggan (Y) berpengaruh secara positif dan signifikan terhadap loyalitas pelanggan (Z).

\section{b. Saran}

Adapun saran-saran yang dapat dipertimbangkan sehubungan dengan hasil penelitian adalah sebagai berikut :

1. Kualitas pelayanan mempunyai pengaruh besar terhadap kepuasan pelanggan. Hal ini menunjukkan bahwa kualitas pelayanan yang baik akan berpengaruh terhadap kepuasan pelanggan para pelanggan di Rumah Makan Waroeng Desa Karawang. Berdasarkan hasil tanggapan responden terdapat indikator yang dirasa masih kurang yaitu kebersihan. Responden mengharapkan Rumah Makan Waroeng Desa Karawang dapat menyediakan tempat yang terpelihara dan nyaman serta bersih agar pelanggan merasa nyaman dan puas dalam melakukan pembelian di rumah makan tersebut. Adapun upaya dari Rumah Makan Waroeng Desa Karawang untuk menciptakan kebersihan yaitu dengan membersihkan tempat yang sudah digunakan mulai dari meja hingga lantai, dan untuk kebersihan toilet, dengan membersihkan setiap sudut toilet sebelum rumah makan buka hingga saat setelah dipakai oleh banyak pelanggan.

2. Bauran pemasaran harus selalu diperhatikan, karena bagi suatu perusahaan promosi sangat penting agar semua masyarakat mengetahui perusahaan tersebut. Berdasarkan hasil tanggapan responden terdapat indikator yang dirasa masih kurang yaitu promosi yang belum tersebar melalui media cetak dan kebersihan toilet dan mushola. Responden berharap promosi dilakukan melalui media cetak seperti brosur-brosur, Koran harian karawang, dan pamflet, dan untuk kebersihan toilet dan mushola, responden pun berharap bahwa Rumah Makan 
Waroeng Desa Karawang agar lebih memelihara kebersihan agar para pelanggan yang datang merasa nyaman.

Adapun upaya dari Rumah makan untuk masalah promosi yaitu dengan menyebarluaskan pamflet dan aktif di media social serta bekerja sama dengan pihak media cetak agar bisa mempromosikan rumah makan ini di Koran-koran ataupun majalah. Dan untuk kebersihan toilet, dengan membersihkan setiap sudut toilet sebelum rumah makan buka hingga saat setelah dipakai oleh banyak pelanggan. Dan kebersihan mushola dengan rutin mencuci mukena, sarung dan sajadah sebulan 2x, dan merapikan kembali pada tempat yang sudah disediakan.

3. Rumah Makan Waroeng Desa diharapkan terus dapat meningkatkan kepuasan pelanggannya agar dapat mempertahankan dan meningkatkan loyalitas pelanggan serta menarik pelanggan lain. Berdasarkan hasil penelitian terdapat indikator yang masih kurang yaitu adanya complain atau keluhan dari pelanggan terhadap pelayanan maupun produk. Responden mengharapkan kualitas pelayanan ataupun produk dari Rumah Makan Waroeng Desa agar lebih ditingkatkan kembali, dan pelanggan mendapatkan kepuasan setelah membeli produk dari rumah makan. Sehingga loyalitas pelanggan pun meningkat.

Adapun upaya dari rumah makan agar pelanggan tidak mengeluh yaitu dengan meningkatkan kembali kualitas pelayanan seperti melayani dengan sigap dan cepat bila pelanggan membutuhkan sesuatu, atau melayani complain pelanggan. Dan untuk kualitas produk seperti menyajikan masakan nya agar terlihat unik dan menarik sehingga pelanggan mau memilih produk tersebut, dan terjaga juga kebersihan produk itu sendiri.

4. Adapun kajian atau penelitian lebih lanjut tentang variabel lain yang mempengaruhi loyalitas pelanggan pada Rumah Makan Waroeng Desa Karawang sehingga diharapkan Rumah Makan Waroeng Desa Karawang menjadi rumah makan pilihan dan favorit masyarakat Karawang.

\section{DAFTAR PUSTAKA}

Kotler, Philip. 2000. Manajemen Pemasaran Edisi Milenium. Jakarta : Prehallindo

Kotler, Philip, dkk. 2005. Manajemen Pemasaran Edissi Kesebelas Jilid 2. Jakarta: PT.Indeks

Kotler, Philip., and Armstrong. 2012. Marketing Management. $14^{\text {th }}$ Edition. Pearson Prentice Hill

Lovelock, Christopher dan Wirtz, Jochen. 2011. Service Marketing : People, Technology, Strategy. $7^{\text {th }}$ Edition. New Jersey : Pearson Education Inc.

Morissan. 2007. Periklanan Komunikasi Pemasaran Terpadu. Jakarta : Ramdina Prakarsa

Ratih Hurriyati. 2010. Bauran Pemasaran dan Loyalitas Konsumen. Bandung : Alfabeta

Riduwan. 2003. Dasar-dasar Statistika Edisi Ketiga. Bandung : Alfabeta

Zeithaml, V,A \& Bitner, M,J. 2003. Service Marketing edisi 3. New York: McFrawHill 